\title{
Hugo Pratt y la estética masónica: Corto Maltés, ¿el último romántico masón?
}

\author{
Hugo Pratt and the Freemasonic Aesthetic: \\ Corto Maltese, The Last Romantic Mason?
}

\author{
David Martín López \\ Universidad de Granada, España \\ dml@ugr.es \\ Antonio Jiménez Nievas \\ Universidad de Granada, España \\ ajnievas1996@gmail.com
}

Recepción: 23 de octubre de 2018/Aceptación: 18 de noviembre de 2018.

doi: https://doi.org/10.15517/rehmlac.v10i2.34965

Palabras clave

Hugo Pratt; Corto Maltés; cómic; estética masónica; simbolismo; esoterismo; sociedades secretas.

Keywords

Hugo Pratt; Corto Maltese; comics; masonic aesthetics; symbolism; esoterism; secret societies.

Resumen:

Este artículo, con un marcado componente multidisciplinar, aborda la manera que ha tenido el cómic de plasmar el hecho masónico, principalmente centrándose en la obra paradigmática del artista francmasón italiano Hugo Pratt (1927-1995) y, especialmente, en su personaje Corto Maltés (1967-1992).

Abstract

The aim of this paper, with an holistic approach, is to reconsider the masonic fact in the art work of the freemason Italian cartoonist Hugo Pratt (1927-1995) and, specially, in that of his main character Corto Maltese (1967-1992).

\section{Introducción: Sobre arte, estética masónica y medios de masas}

Antes de introducirnos específicamente en el mundo del cómic, y más concretamente en la producción del historietista italiano y francmasón Hugo Pratt (19271995), debemos señalar la relación que ha mantenido la masonería con el arte dirigido hacia las masas. Esta cuestión no es arbitraria, puesto que la masonería desde sus orígenes especulativos en la Inglaterra del siglo XVIII ha fomentado la discreción de sus actuaciones y manifestaciones socioculturales, es decir, su herramienta más segura para su difusión y éxito transnacional. Por lo tanto, ¿cómo interactuar con la sociedad y con los medios de masas? He ahí la disyuntiva teórica e ideológica que buena parte de la hermandad del Gran 
Arquitecto del Universo va a mantener a lo largo de siglos. Ha habido intensos debates desde tiempos remotos - casi desde sus orígenes- sobre qué papel tenía que jugar el artista dentro de la Orden, debido al miedo a la profanación de los secretos que esconde el símbolo.

En estas fechas, miembros díscolos y superdotados de creatividad artística -como puede ser el caso del pintor y grabador inglés francmasón William Hogarth (1697-1764)dan buena muestra de ello dentro de su obra gráfica Los cuatro momentos del día (1736). En ésta, y más concretamente, en el trabajo La noche (1736), se aprecia la salida de una tenida masónica cerca de Picadilly Circus en Londres, en la que un Venerable Maestro debido al influjo del alcohol "consumido" durante la celebración masónica de la tabernaha olvidado retirase la joya de grado que lo identifica, además del mandil y el sable que porta su hermano, éste ya descaracterizado de su atuendo y regalías.

Nos encontramos -así- con una de las primeras críticas artísticas e internas en clave masónica, dirigidas tanto a los miembros masones británicos como al gran público en la que Hogarth, con su característica sátira, rechaza la excesiva ingesta de alcohol en las tenidas y fiestas masónicas londinenses. El autor, mediante este grabado, enmarcado dentro de una serie no masónica - esto es significativo-, se dirige a un público no familiarizado con la simbología de la orden. Y, asimismo, expresa su rechazo hacia la degradación y promiscuidad del símbolo masónico en esta época. Desde un punto de vista teórico, interesa tanto este grabado como este hecho, puesto que, en la praxis masónica, una de sus premisas es no desvelar ni el secreto masónico, ni el grado ni posición dentro de la orden. De esta forma se entiende la adopción, a lo largo de su historia -en función de la cronología y el contexto geográfico-, de diferentes recursos para esta cuestión. Por ejemplo, el empleo de nombres simbólicos en el interior de la logia y en los documentos oficiales de la misma. Hasta tal punto es el celo del símbolo masónico que en las tenidas existe una figura clave. Se trata del guarda templo exterior que vigila que ningún profano - es decir, ningún un intruso-, pueda tener contacto visual con la producción simbólica y ritualística que se ejecuta durante los trabajos.

Normalmente, la historiografía del arte no ha considerado la estética masónica, bien por desconocimiento o por la complejidad que supone su análisis, dentro de las lógicas disquisiciones científicas al uso. En este sentido, la historia del arte omite la adscripción masónica de un autor como hecho biográfico, hasta en artistas consolidados en el panteón de masones ilustres: el caso de propio Marc Chagal (1887-1985), Frédéric Auguste Bartholdi (1834-1904), Juan Gris (1887-1927), muchos de ellos - incluso- grados 33, como Alphons María Mucha (1860-1939) en la Gran Logia checa y altos cargos como Ettore Ferrari (1845-1929), gran maestro del Gran Oriente de Italia. ¿Por qué ocurre este hecho?

Esto no es objeto de debate ni discusión teórica en estas líneas, al no poder abordar esta cuestión de manera sucinta. Si bien resulta significativo la notable ausencia de la historia del arte en todo lo que concierne al estudio del simbolismo masónico. Desde un 
punto de vista formal, la masonería es una de las pocas instituciones asociativas de carácter universal que trabaja simbólicamente con aspectos relacionados con la arquitectura, la geometría y la belleza. No obstante, aunque no es una de sus prioridades o finalidades, la orden usa toda la retórica del símbolo para mayor comprensión iniciática y solidez de su discurso. Por ello, cuando actúa en el contexto urbano, en el medio profano, ante la sociedad de masas, denota una intencionalidad estética del todo inusual.

Es bien sabido que, aunque los orígenes del cómic se puedan retrotraer incluso a la Columna de Trajano o a escenas más coordinadas en "viñetas" narrativas y pictóricas durante la Edad Media - con Giotto como una especie de padre primigenio por su manera de trasmitir las escenas espacio-temporales de la vida de san Francisco-, no será hasta llegado el siglo XVIII con Hogarth, y sobre todo en el siglo XIX con Honoré Daumier (1808-1879), cuando el cómic adquiera su protagonismo y se preconice en su devenir plástico y estético futuro.

El cómic -junto al cine y la fotografía- llegará a ser en el siglo XX uno de los medios de expresión artísticos más importantes. Al fin y al cabo, su tirada -con vocación, en ocasiones, internacional- y su repercusión mediática afectan a la sociedad, ávida de consumo de historias tras la II Guerra Mundial y deseosa de válvulas de escape de la realidad en la que está inmersa. El cómic, hasta la llegada de internet -e, incluso, tras su aparición-, ha sabido subsistir y se ha categorizado como el noveno arte, después de la fotografía y el cine. Los historiadores que se acercan a él intentan clasificarlo como un género literario más, pero su recurso visual es tan potente que no podríamos encorsetarlo en esta fórmula.

De hecho, el propio Hugo Pratt lo consideraba como "[...] el cine de los pobres". Una expresión llena de matices interesantes. Por un lado, el autor está subrayando la potencia visual del cómic -a modo de sucesión de fotogramas cinematográficos-, así como su sentido narrativo. Al mismo tiempo, se advierte un posible sentido filantrópico de accesibilidad a este medio de comunicación y expresión artística, puesto que se dirige a un público más amplio, universal. De hecho, hay que tener en cuenta que la audiencia, sin apenas saber leer las propias viñetas, puede captar la esencia del argumento.

La relación contemporánea de la masonería, con la difusión en internet y los medios de comunicación, ha cambiado radicalmente. Y lo ha hecho hasta el punto de existir actualmente- un documental como 33 \& Beyond: The Royal Art of Freemasonry (2017), escrito y dirigido por Johnny Royal, quien a lo largo de siete años documentó la sociedad masónica estadounidense. En la misma línea, Europa posee un interesante ejemplo en la serie documental Inside the Freemasons (2017), de Ian Pleasance, disponible en la plataforma Netflix. En ella puede apreciarse la historia actual de los masones anglosajones, observando su día a día en las diferentes salas de la Gran Logia de Inglaterra, así como de

\footnotetext{
${ }^{1}$ Antonio Ballesteros y Claude Duée coords., Cuatro lecciones sobre el cómic (Cuenca: Ediciones de la Universidad de Castilla La Mancha, 2000), 11.
} 
otros talleres británicos. De esta forma, se desmitifica el sentido secreto de sus actividades, aunque no entra en conflicto con la preservación del Rito. Se trata de una labor de normalización mediática, que -en cierto modo- el propio Pratt había preconizado con la edición de sus cómics de Corto Maltés, sobre todo, en el caso de la Fábula de Venecia (1977).

Otros medios de comunicación de masas - como el cine- se habían enfrentado, desde inicios del siglo XX a la problemática de cómo afrontar lo masónico. Entre los ejemplos, se pueden mencionar la comedia Are you freemason? (1915), así como otra versión homónima de años más tarde (1934), inspiradas en una obra teatral alemana homónima (Fig. 1). En la obra de 1915, dirigida por Thomas N. Heffron, vemos a John Barrymore (1882-1942). El protagonista es Frank Perry, un excéntrico alcohólico, trata de convencer a su esposa que su borrachera idiosincrática es parte de los rituales masónicos de iniciación ${ }^{2}$.

\section{Hugo Pratt: Consideraciones previas a Corto Maltés}

El estudio que nos ocupa gira en torno a la producción de Hugo Pratt (1927-1995), dibujante de cómic italiano nacido en las cercanías de Rímini. Su origen judío y su ascendencia familiar nos indican las influencias estéticas y sincréticas de su obra.

Es importante subrayar el peso cultural de lo judaico en su vida y en su obra. No solo son aspectos que están relacionados con el hermetismo simbólico del que hará gala a lo largo de su trayectoria profesional, sino que también conlleva el empleo de otras referencias estéticas de novelistas gráficos judíos contemporáneos ${ }^{3}$. En el imaginario de Hugo Pratt se dan cita la tradición sefardí -en contraposición de la primacía de lo asquenazí, imperante en la cultura judaica europea-, la cábala judía y el simbolismo de la masonería especulativa de raigambre francesa. Todo ello se entrelaza con alusiones culturales y literarias de diversas cronologías, desde Tomás Moro, a Shakespeare, pasando por Jack London, Herman Hesse o Saint-Exupéry ${ }^{4}$. Pratt es, ante todo, un bibliófilo empedernido, con una inmensa cultura. Y esto se demuestra en su extensa biblioteca de más de 30.000 volúmenes $^{5}$. Libros que oscilaban desde códices mayas a novelas judías del siglo XX. Estamos ante un paradigma que va más allá de la propia novela gráfica para convertirse en un pensador y filósofo alabado, entre otros, por Umberto Eco (1932-2016),

\footnotetext{
${ }^{2}$ Bodeen DeWitt, From Hollywood: The Careers of 15 Great American Stars (Los Ángeles: A. S. Barnes, 1976), 173.

${ }^{3}$ Sobre este aspecto, Ricardo Anguita Cantero, "Historia, tradición y memoria en la novela gráfica judía (1976-2010)", en Para entender el judaísmo: sugerencias interdisciplinares, coords. Lorena Miralles Maciá y Elvira Martín Contreras (Granada: Universidad de Granada, 2012), 353-382.

${ }^{4}$ En este sentido, Hugo Pratt le dedica un cómic Saint-Exupéry. El último vuelo, en 1995 con prólogo de Umberto Eco.

${ }^{5}$ Javier Navascué, "Borges, Pratt y Corto Maltés: convergencias y malas lecturas", Variaciones Borges. Revista del Centro de Estudios y Documentación Jorge Luis Borges 43 (2017): 161.
} 
quien aseguraba que, si para divertirse leía a Hegel, para reflexionar ojeaba los cómics de Hugo Pratt ${ }^{6}$.

Regresando al autor de Corto Maltés, y comenzando por la línea paterna, su abuelo Joseph Pratt era de origen anglo-francés, proveniente de Cornualles, donde se había instalado la familia tras la invasión normanda de Inglaterra. Según aseguró Hugo Pratt en una entrevista a Numa Sadoul ${ }^{7}$, su familia regresó exiliada a Francia en torno a 1700, al ser católica. Su abuelo Joseph ya nacería en Lyon, trasladándose posteriormente a Venecia, donde echó raíces, pero sin renunciar a su nacionalidad británica ${ }^{8}$. Su abuela paterna era veneciana, descendiente de una familia sefardí, los Toledano. La línea materna, de origen sefardita, eran comerciantes establecidos en la ciudad del Véneto y convertidos al cristianismo. Se trataba de los Gennaro, familia de adopción de su abuelo Eugenio Genero.

$\mathrm{Su}$ abuela materna era de procedencia turca mientras que su abuelo materno -de origen judío-sefardí- era Eugenio Genero (1875-1947), un poeta y podólogo relevante en Venecia. Eugenio Genero era hijo ilegítimo de una noble familia sefardita, afamada en esta ciudad como la de los joyeros Zeno-Toledano. Su infancia, hasta los 10 años, fue feliz y despreocupada. Pratt estaba rodeado siempre de su abuela materna, que ejerció gran influencia en el muchacho. De hecho, le introdujo en el mundo del arte y en el interés por los asuntos esotéricos. Su madre, Evelina Gennaro, tiraba las cartas del tarot a sus amigas a modo de diversión, convirtiéndolo con posterioridad en una práctica lucrativa. Y con su tía descubrió el apasionante mundo de la mitología y de los misterios de la cábala, al mismo tiempo que le transmitía su pasión por la ópera, principalmente wagneriana. De hecho, acudían juntos al teatro de La Fenice a ver la tetralogía operística El anillo de Los Nibelungos (1876).

En 1937, Pratt abandonó su amada Venecia y se trasladó al continente africano. Su padre, oficial del ejército de Mussolini, había sido destinado a Abisinia, actual Etiopía y antigua colonia italiana. Durante su adolescencia africana, el autor -enrolado en la policía colonial como cadete benjamín- se familiarizaría con realidades exóticas y contextos del Mediterráneo que posteriormente tendrían un reflejo en su obra. Exotismo y realidad militar se dan la mano en África. Un microcosmos donde las revistas militares y las tradiciones locales marcarán las influencias estéticas de Pratt ${ }^{9}$. Para él, el recurso de lo exótico no era una cuestión simplemente estética dentro de sus cómics. De hecho, en su propia manera de

\footnotetext{
${ }^{6}$ Paolo Beltramin, "Corto Maltese, il romanziere a fumetti più grande di tutti”, en Corriere della sera, 11 de abril de 2014 , https://www.corriere.it/cultura/14 aprile 11/corto-maltese-romanziere-fumetti-piu-grande-tutti-165fe97e-c15d-11e39f36-c28ea30209b6.shtml

${ }^{7}$ Numa Sadoul se caracterizaba por entrevistas agudas a los escritores de cómic como el belga creador de las Aventuras de Tin-Tin, Hergé (1907-1986) o Hugo Pratt.

${ }^{8}$ Sadoul, "Una comida con Hugo Pratt", Entrevista al autor realizada por Numa Sadoul en Saint-Germain-en-Laye el 18 de diciembre de 1978 y publicada en Les Cahiers de la Bande Dessinée, Editions J. Glenat, Francia. Numa Sadoul, "Una comida con Hugo Pratt", Totem 6 (1978): 87-98.

${ }^{9}$ Guzmán Urrero Peña, “América en las historietas de Hugo Pratt”, Cuadernos Hispanoamericanos 568 (1997): 19.
} 
contar su biografía aclamaba haber nacido en medio de una playa exótica, tal y como sugiere el famoso periodista británico James Kirkup (1918-2009) ${ }^{10}$.

Durante su estancia en el continente africano, su padre, Rolando, fue apresado por el ejército aliado, siendo retenido en un campo de concentración francés, donde falleció a causa de unas fiebres en 1943. Tras la muerte de su progenitor, Evelina y su hijo decidieron volver a Venecia. Esta vuelta no estuvo exenta de vicisitudes, ya que, tras su regreso, Venecia se hallaba en control alemán y el propio Pratt estaba bajo sospecha de las SS, por lo que fue arrestado y acusado de espionaje. En un primer momento, fue forzado a colaborar con el ejército nazi, lo que le hizo huir y cambiar de bando para poder trabajar con los aliados como intérprete.

En 1945 conoció a Mario Faustinelli (1924-2006), reconocido dibujante y fundador de la revista Albo Uragano, posteriormente denominada Asso di Picche (1947). Fue la etapa en la que entró a formar parte, junto a Faustinelli, del autodenominado Grupo de Venecia, constituido -entre otros- por los artistas Giorgio Bellavitis (1926-2009), Dino Battaglia (1923-1984), Ivo Pavone (1929) y el escritor Alberto Ongaro (1925-2018).

Una vez concluida la Segunda Guerra Mundial nos encontramos con un joven Hugo Pratt de 22 años que se afincó en Argentina -junto a Ongaro, Pavone y Faustinelli- tras la invitación a trabajar para la editorial Abril, dirigida por César Civita (1905-2005). Su renombrado director solía afirmar "en Abril no somos anti nada. Excepto antinazis y antifascistas" ". Pratt trabajó en la serie Junglemen. Dentro de esta etapa argentina entró en contacto con Héctor G. Oesterheld (1919-1977), uno de los autores literarios con los que el dibujante italiano desarrolló su labor más destacada: El sargento Kirk (1953) en la revista Misterix y Ernie Pike (1957), para Hora Cero de Ediciones Frontera. Ya en 1962 encontramos la obra que reconoció su trayectoria: Fort Wheeling, experiencia previa a Corto Maltés.

Nuestro autor regresó a Italia en 1963 debido a la crisis económica argentina. En su nuevo destino, y gracias a la amistad con el empresario Florencio Ivaldi, se le presentó la oportunidad de editar una revista llamada Sargento Kirk, en clara alusión a uno de sus personajes creados durante el periodo argentino. En esta revista reeditó para el público italiano toda su producción argentina. Además, en dicha editorial genovesa, Ivaldi, nuestro autor efectuó una serie titulada Una balatta del mare salato, en el que apareció su nuevo personaje, Corto Maltés, por el cual se reconoce a Pratt en la actualidad. Debido a la gran fama alcanzada por dicha creación, acabó trasladándose a París, ciudad del cómic por excelencia. Allí entró en contacto con la revista Pif y fue en estos momentos cuando Corto

\footnotetext{
10 James Kirkup, "Obituary", The Independent, 31 de agosto de 1995, https://www.independent.co.uk/news/people/obituary-hugo-pratt-1598750.html

${ }^{11}$ Susana Viau, "Lo de siempre, la historia se burla de quieren repetirla", 29 de agosto de 2010, en La reina de corazones. No es más que un naipe de la baraja: Las columnas de la periodista que le arruinó los domingos a CFK (Buenos Aires: Penguin Random House Grupo Editorial Argentina, 2013).
} 
Maltés se convirtió en un héroe de serie que saltó a la fama internacional, publicándose un total de doce historias a lo largo de 25 años ${ }^{12}$.

\section{Un maltés en Venecia: Donde lo hermético se hace luz}

Hugo Pratt se inició en noviembre de 1976 -con 49 años- en la logia Hermes de la ciudad de Venecia, un taller del que formó parte los últimos 20 años de su vida. La iniciación vino gracias a su amigo y vecino Luigi Danesin, al que Pratt -tiempo atráshabía mostrado su interés por la masonería tiempo atrás ${ }^{13}$. Curiosamente, la logia pertenecía al Gran Oriente de Italia y había sido sede de un episodio dramático que, en la vida de Pratt, marcaría un antes y un después. Su padre había estado implicado como miembro de las fuerzas fascistas de Mussolini en desmantelar Hermes. Incluso, se quedó con un sable ritualístico perteneciente al Venerable Maestro. Este elemento sería devuelto por Hugo Pratt tras su iniciación masónica en dicha logia, retornando el mal causado por su progenitor.

En 1989, Hugo Pratt se adscribió al Consejo Supremo de Italia del Rito Escocés Antiguo y Aceptado. Ingresó en los altos arados del REAA al ser recibido como Maestro Secreto en la logia Serenissima Perfection del citado Consejo. Esta ceremonia tuvo lugar en Niza en una tenida común con la logia Perfection l'Oliver Secret, del Supremo Consejo y Gran Colegio del Rito Escocés Antiguo y Aceptado del Gran Oriente de Francia. Este nuevo giro de su actividad masónica respondió a la motivación de Pratt por encontrarse a sí mismo y por un sentido francófilo - como apunta su amigo y francmasón Luigi Danesin ${ }^{14}$-, que lo había llevado a seguir el Rito desde Francia. Incluso, poco antes de su muerte, en claro homenaje a su primer gran cómic Fort Wheeling, el dibujante introdujo la iniciación masónica de su protagonista Patrick Fitzgerald en el grado 4 del REAA, dignidad ostentada por el propio Pratt (Fig. 2).

Desde la primera aparición de Corto Maltés en escena, en la Balada del Mar Salado (1967), Pratt confirió conocimientos esotéricos a este personaje hermético y sofisticado, marinero de Malta errante por los mares del mundo y amante de Venecia -ciudad a la que siempre volvía con nostalgia y anhelo-. Corto, con cierto halo de dandi, poseía gran avidez intelectual no solo para descifrar aspectos cabalísticos y esotéricos, sino también otros que se fundían sincréticamente con leyendas masónicas y con el propio Templo de Jerusalén. En esta obra ya podemos apreciar el interés del autor por las sociedades secretas o «discretas», puesto que el propio Corto pertenecía a una sociedad secreta de piratas que

\footnotetext{
12 Marco Steiner, "Biografía de Hugo Pratt”, Página oficial de Corto Maltés, https://cortomaltese.com/es/hugo-pratt/

13 Juan Manuel Bellver, "El masón de Venecia", El Mundo, 1 de marzo de 2012, http://www.elmundo.es/elmundo/2012/03/01/cultura/1330600450.html

${ }^{14}$ Ricardo Serna, "Masones en el Cómic. La Masonería y Corto Maltés", en Estudios Masónicos. Cinco ensayos entorno a la Francmasonería (Santa Cruz de Tenerife: Ediciones Idea, 2008), 159-214.
} 
obedecían a un personaje misterioso llamado El monje, con base de operaciones radicada en la isla de La Escondida, situada en el Océano Pacífico.

En otra de sus aventuras, en Las Célticas (1971), recopilación de relatos cortos realizados por Hugo Pratt y creados bajo este título -siendo el primero el cómic Sueño de una mañana de invierno-, ya se advertía todo el corpus simbólico que acompañaría siempre a Corto en sus posteriores andanzas. Esta obra hace clara referencia al Sueño de una noche de verano (1600) de William Shakespeare, así como a la mitología artúrica. Corto -quien argumenta: "Stonehenge, nombre antiguo en la geografía de la magia y la leyenda"- se queda dormido frente al gran crómlech (Fig. 3). Allí, en Stonehenge, tiene un sueño visionario en el que se le aparece una serie de personajes mitológicos de la tradición céltica británica: el mago Merlín, Oberón, rey de los elfos, Puck y el hada Morgana. Con un sentido mesiánico, los personajes mitológicos designan a él mismo como un nuevo rey Arturo, cuya función es salvar a Inglaterra del mal sajón en la Gran Bretaña de la Primera Guerra Mundial. Todo ello conecta en cierta forma con toda una tradición hermética y una visión onírica del mundo anglosajón, donde la fantasía prima, tal y como sugiere Rubis ${ }^{15}$.

Se ha de señalar que la masonería británica desde el siglo XVIII ha reivindicado este patrimonio arqueológico, en un intento de conexión entre las logias operativas medievales y las viejas técnicas ancestrales del pasado británico, al igual que artistas francmasones como Joseph Gandy (1771-1843) ilustraban de forma gráfica -a lo largo del siglo XIX- el imaginario de la tumba del mago Merlín ${ }^{16}$. Incluso hacían peregrinaciones y formaban sociedades de carácter geográfico inspiradas en el asociacionismo masónico británico.

Además, otro dato -en ocasiones denostado y no considerado relevante- es que la propia Orden de los Druidas ${ }^{17}$, constituida en las mismas fechas de la masonería especulativa, exigía para su membresía la necesidad de ostentar el tercer grado masónico. Es decir, ser un maestro masón. De ahí que se conserven numerosos grafitis en las mismas piedras alusivas a firmas de masones, algunas de ellas datadas en $1802^{18}$. Albert G. Mackey (1807-1881), ahondando en los orígenes de la francmasonería anglosajona, mencionaba la complejidad de asimilar que los druidas pudieran haber construido el complejo megalítico, pero el desciframiento del enigma no era asunto tanto de la masonería sino de la

\footnotetext{
${ }^{15}$ Ver afirmación de Florián Rubis, "La Balada del Mar Salado", en The Expanding Art of Comics: Ten Modern Masterpieces, ed. Thierry Groensteen (Jackson: Missisipi University Press, 2017).

${ }^{16}$ David Martín López. "La revalorización del medievo en la estética masónica: Inglaterra y Escocia (siglos XIX y XX)", Medievalista 15 (2014): 1-28.

${ }^{17}$ Mark Stavish, Freemasonry: Rituals, Symbols \& History of the Secret Society (Minnesota: Llewellyn Editions, 2007), 211.

${ }^{18}$ Noticia del Blog sobre Stonehenge, sin autor: "Freemasons and Stonehenge. The Masonic Connection", 14 de diciembre de 2016, https://blog.stonehenge-stone-circle.co.uk/2016/12/14/freemasons-and-stonehenge-the-masonicconnection/
} 
arqueología ${ }^{19}$. Aquí podemos apreciar también otras referencias cuanto menos filomasónicas.

Además, también se aprecian influencias de carácter hermético en Corto Maltés en Siberia (1974), donde existe un gusto por lo esotérico y, específicamente, por las sociedades secretas, como las Triadas chinas. Los títulos originales del autor italiano denotan una clara intencionalidad y conocimiento de las referencias estéticas del hermetismo simbólico occidental y del conocimiento judeocristiano.

En realidad, podríamos afirmar que la historia de Corto Maltés parece -en cierto modo- una especie de biografía de Pratt, un alter ego inclusive en lo que respecta a su iniciación masónica. Los vínculos con la veneciana logia Hermes, así como la atmósfera sociopolítica del momento que recrea esta obra, entroncan directamente con una serie de vivencias y sucesos acaecidos en la ciudad de los canales. Será en esta logia -y no en otraen la que Corto también aparecerá.

En la edición del 50 aniversario de la Balada del Mar Salado encontramos una introducción biográfica e ilustrada sobre Corto Maltés, donde se advierten las principales características del autor y del protagonista a lo largo de su inseparable vida. Corto, según Hugo Pratt, nace en la Valeta, capital de Malta, en 1887. Hijo de una gitana sevillana y de un padre británico, al igual que Pratt estudia la Cábala y adquiere conocimientos herméticos. Encontramos más paralelismos, ya que la madre de Corto - como la del autortiraba las cartas y poseía cierta clarividencia.

Fábula de Venecia. Sirat Al-Bunduqiyyah (1977) es la séptima publicación de la saga de Corto Maltés. Fruto del azar o no, se trata de un número nada desdeñable dentro de la perspectiva simbólica. Y el primero en el que se advierte un claro conocimiento de la masonería. Pratt se había iniciado un año antes en la Logia Hermes Trimegisto de Venecia, por lo que el simbolismo aquí no tiene aspectos filomasónicos sino que por el contrario dialoga perfectamente con sus miembros hermanos.

En este cómic encontramos referencias directas del simbolismo visual y estético de la orden del Gran Arquitecto del Universo. Este acercamiento de la masonería al gran público refleja el deseo de Pratt de conferir cierta visibilidad a lo masónico, dada la relevancia del personaje de Corto Maltés. Y, al mismo tiempo, el manejo diestro de un corpus más complejo, de un lenguaje que solo el masón de alto grado puede decodificar, nos permite conectar con esa erudición reflexiva a la que aludía Umberto Eco. No se trata tanto de elementos arbitrarios ni palabras sin sentido escritas como criptogramas en los lomos del león -frente al Arsenal- o en el paisaje urbano de la ciudad de Venecia. Como en masonería, nada hay arbitrario. Y tampoco existe este parámetro en las referencias visuales y simbólicas de Pratt en este cómic.

${ }^{19}$ Albert Gallatin Mackey, The History of Freemasonry: Its Legendary Origins (Nueva York: Dover Publications, 2008), 207. 
El mismo nos cuenta una nueva aventura de nuestro protagonista en Venecia. Corto se encuentra en la ciudad debido al reto que le presenta el barón Corvo, que a través de un acertijo le anima a encontrar un tesoro conocido como la Clavícula de Salomón. Una esmeralda que, según la tradición, había sido llevada a la ciudad de Venecia por los caballeros templarios junto al cuerpo de San Marcos. La acción se enmarca en 1921. La historia comienza con Corto huyendo de ciertos grupos pro-fascistas a través de los tejados de la urbe. De repente, cae y acaba atravesando una bóveda de cristal, razón por la cual interrumpe los trabajos de la respetable logia Hermes (Fig. 4). Era una tenida masónica envuelta de secretismo al encontrarse el foco fascista en la ciudad y, por tanto, al estar las acciones masónicas en el punto de mira. De ahí que sus miembros se encontrasen encapuchados, no siendo identificables sus facciones y solo pudieran ser reconocidos por sus regalías de grado. Esta descripción conectaría con otros cómics -como Las aventuras de Tin Tín (1930-1976) de Hergé (1907-1983) - y con formas de desvelar cierto hermetismo de las logias europeas, como sucede con el paradigmático mediometraje Forces occultes (1943) del cineasta Jean Mamy (1902-1949), francmasón adscrito al GODF y que -bajo seudónimo de Paul Rich, y tras la llegada de los alemanes de Hitler- quedó convertido en un ferviente antimasón. No obstante, el relato de la mencionada tenida también hace recordar - en cierto modo- a la manera expositiva de algunas muestras antimasónicas alemanas y belgas con las llegadas de los fascismos a Europa. O, incluso, a la recreación de una logia con los bienes masónicos incautados por Franco y conservada en el Centro de Documentación de la Memoria Histórica de Salamanca, en la que también aparecen personajes encapuchados.

Estamos ante la primera vez que en el cómic de Pratt aparecen elementos masónicos con una pureza estética inusual en la época. Tanto las joyas de grado como las demás regalías masónicas -mandiles, bandas, etc.- y otros elementos de la logia -mallete, candelabro de siete brazos, escuadra y compás, o la misma decoración del taller-, podríamos decir que se asemejan al ornato y a la estética masónica contemporánea a las fechas en la que se narra la historia. Pero también interpretamos una serie de símbolos más herméticos que solo son descifrables para los iniciados - gestos de paso, mitos y leyendas asociadas a grados, etc.-. En este sentido, encontraríamos grimorios como La Clavícula de Salomón, primordial dentro de la literatura mágica que conecta la magia del rey Salomón con la propia historia del templo ${ }^{20}$. E, incluso, conjuros mágicos, como la mano de Fátima que aparece en la visión que tiene tras su caída (Fig. 5). En ésta también aparece el sello de Salomón en su centro y algunas de las palabras en caligrafía árabe, como las terminaciones $a y l, z a$, denotan fórmulas mágicas asociadas al número tres. En realidad, todo ello debe entenderse como una especie de talismán protector contra los demonios.

${ }^{20}$ William J. Hamblin. El Templo de Salomón. Historia y Mito (Madrid: Akal, 2008), 181. 
Tras la irrupción en la tenida, Corto es preguntado por el Venerable Maestro si es un hermano debido al conocimiento que posee de los símbolos masónicos, a lo que él responde que tan solo es un "francmarino". Una vez más, la ironía del personaje y el sentido simbólico del término se entremezclan. Seguidamente, el Venerable Maestro le invita a olvidar lo sucedido y abandonar la logia. Corto continúa su periplo en busca de la esmeralda protectora de Salomón, denominada la Clavícula de Salomón. En este periplo entra en contacto con Hipatia, personaje con un profundo conocimiento. Tras este primer encuentro Corto va descifrando las diferentes pistas del barón Corvo que lo llevarán por diversos enclaves de la ciudad. Es en este momento cuando Pratt introduce un crimen en la trama y Corto se ve acusado del mismo, teniendo que huir de las autoridades, cayendo de los tejados y quedando malherido. En su recuperación tiene una visión donde conoce a un Rasputín ataviado como un genio, le narra la historia de la piedra que busca. Tras estos hechos, se dirige a la logia Hermes, donde advierte el sello de Salomón, el lugar donde se encontraba escondida la clavícula. Pero cuando nuestro aventurero retira el sello encuentra una carta del barón Corvo donde se burla de él.

En la escena del crimen, Corto encuentra una medalla masónica -representación del grado de preboste del Rito Escocés Antiguo y Aceptado, inspirado casi con total seguridad en la versión iconográfica de Les Blassons des 33 Grades de L'Écossisme d' après Loth (1875) - y decide hablar con el Venerable Maestro. Éste le comenta que pertenece a un antiguo rito y le pide nuevamente que olvide todo lo que ha visto. De repente, un fuego se extiende por la logia. Corto huye junto con el Venerable Maestro e Hipatia, cuando súbitamente- es atacado por un masón. Éste le vence y, al quitarle la capucha, descubre que su atacante es Falero, quien le explica que tenía que acabar con él para encubrir a Hipatia por haber matado a Stevani, evitando así que pudiera consultar el diario del barón Corvo. Tras estos acontecimientos, la narrativa cambia y nos encontramos en otro plano, en el que Corto consigue la Clavícula de Salomón y todos los personajes que han aparecido en la trama saludan al lector y Corto abandona así la historia.

Esta obra de Pratt es interesante desde dos puntos de vista. Por un lado, nos relata una historia donde la trama masónica tiene un peso específico. Y, por otro, observamos cómo este episodio de Corto es la narración de una de las vivencias de Pratt. Así, hacia el final del cómic, se otorga importancia a la figura del guarda templo interior que porta la espada o sable ritual. Esta relevancia viene dada por la historia familiar, ya que -como habíamos señalado anteriormente- su padre robó la citada espada durante la época de Mussolini. Por tanto, no es baladí la presencia -en tres viñetas-de esta singular e histórica pieza. Además, se muestran referencias específicas al grado cuarto de Maestro Secreto, dignidad que ostentaba el propio Pratt. Entre ellas, el mandil de grado con el anagrama Z, al igual que algunas $\mathrm{Z}$ que aparecen grabadas en la pared junto a elementos geométricos herméticos. 
Tanto la Casa dorada de Samarkanda (1980) ${ }^{21}$, como Las Helvéticas (1987) y Mû (1988), responden a planos esotéricos propios de un mundo complejo, en el que Pratt se había adentrado. Hasta cierto punto, el lector -ávido de aventuras de Corto- no supo entender la profundidad de tales relatos. Serán Las Helvéticas, junto con la referida Fábula de Venecia, las dos obras donde se haga una mayor alusión al símbolo. Y, además, se profundice en éste. Si en la Fábula de Venecia se jugaba con el metalenguaje y un corpus simbólico más asequible para el profano, en esta ocasión todo el aparato iconográfico tiene una marcada raíz hermética de gran dificultad. Se trata de una especie de iniciación. Corto viaja a Suiza, donde tiene contacto con la mitología vernácula a través de un sueño. Una fórmula onírica recurrente en Pratt. En esta ocasión, el recurso de lo wagneriano se vuelve presente con la introducción de un personaje de la ópera Parsifal (1882) de Klingsor, una figura que otros escritores francmasones como Hermann Hesse (1877-1962) y Clemente Palma (1872-1946) usaron en sus respectivas producciones literarias El último verano de Kinglsor y El día trágico (Fig. 6). Corto se encuentra en la búsqueda de la rosa alquímica, importante dentro de los aspectos iniciáticos. Bebe del cáliz, alusión a la ceremonia de iniciación masónica en el siglo XIX en el que el neófito debía mojar los labios de la copa amarga, vinculada de forma esotérica a las tradiciones templarias y a la búsqueda de Santo Grial, cuestión que se alejaría en esta ocasión de la tradición judía y cabalística para adentrarse en campos de hermetismo alquímicos, cristiano-caballerescos, que se escaparían de nuestras pretensiones en este trabajo.

\section{Conclusión}

A modo de conclusión, observamos como la obra de Pratt mantiene un diálogo de marcada erudición con el lector, en el que, a través de las aventuras de nuestro marinero, se hace gala de una serie de conocimientos de una gran profundidad hermética. Expresados éstos de una manera amena y, además, introducidos magistralmente en la trama. De hecho, los mencionados elementos presentan una dualidad inusual en este tipo de género. En ocasiones advertimos como están reflejados de una manera superficial, haciendo referencia directa a la masonería -tal es caso de la Fábula de Venecia-, mientras que otros están dirigidos a un público iniciado en estos conocimientos, como en las Helvéticas. Pese a ello, la Fábula también ahonda en un profundo discurso sincrético del simbolismo que, a buen seguro, llama la atención al masón de alto grado.

En la obra del artista francmasón Hugo Pratt, lo hermético y la tradición judía se dan la mano, presente también en la propia vida de Corto. De hecho, ésta última se constituye como una referencia directa a la biografía de su autor, marcada por las aventuras

\footnotetext{
${ }^{21}$ En ella se hace referencia al manuscrito Memorias griegas de Lord Byron que su amigo Edward Trelawny (1792-1881), novelista y aventurero francmasón, habría escondido en la mezquita Kawakly o la logia Lengua de la Lingua di Francia de la calle de los Caballeros de San Juan en la isla de Rodas.
} 
y la fantasía, el exotismo de la diferencia y por las vivencias transoceánicas. Su adscripción a la orden del Gran Arquitecto del Universo no hizo sino enriquecer el mundo de Corto Maltés y el suyo. A diferencia de otros cómics, la producción del italiano demuestra un soberbio metalenguaje. Tal es así que intelectuales como Umberto Eco reivindicaron su gran valor, estético y filosófico. Toda una lección magistral sobre la que releer pausadamente y adentrarse cuantas veces lo requiera el interesado. El cómic como expresión primordial de un género destinado a los medios de masas pero que, al mismo tiempo, ahonda en el discurso de la erudición y la exclusividad del conocimiento hermético.

\section{Bibliografía}

Anguita Cantero, Ricardo. "Historia, tradición y memoria en la novela gráfica judía (19762010)". En Para entender el judaísmo: sugerencias interdisciplinares. Coordinado por Lorena Miralles Maciá y Elvira Martín Contreras. Granada: Universidad de Granada, 2012.

Ballesteros, Antonio y Claude Duée (coords.). Cuatro lecciones sobre el cómic. Cuenca: Ediciones de la Universidad de Castilla La Mancha, 2000.

Bellver, Juan Manuel. "El masón de Venecia". El Mundo, 1 de marzo de 2012. http://www.elmundo.es/elmundo/2012/03/01/cultura/1330600450.html

Beltramin, Paolo. "Corto Maltese, il romanziere a fumetti più grande di tutti". Corriere della sera, 11 de abril de 2014. https://www.corriere.it/cultura/14_aprile 11/cortomaltese-romanziere-fumetti-piu-grande-tutti-165fe97e-c15d-11e3-9f36c28ea30209b6.shtml

DeWitt, Bodeen. From Hollywood: The Careers of 15 Great American Stars. Los Ángeles: A. S. Barnes, 1976.

Groensteen, Thierry. The Expanding Art of Comics: Ten Modern Masterpieces. Jackson: Missisipi University Press, 2017.

Hamblin, William J. El Templo de Salomón. Historia y Mito. Madrid: Akal, 2008.

Kirkup, James. "Obituary". The Independent, 31 de agosto de 1995. https://www.independent.co.uk/news/people/obituary-hugo-pratt-1598750.html

Mackey, Albert Gallatin. The History of Freemasonry: Its Legendary Origins. Nueva York: Dover Publications, 2008.

Martín López, David. "La revalorización del medievo en la estética masónica: Inglaterra y Escocia (siglos XIX y XX)”. Medievalista 15 (2014): 1-28.

Navascués, Javier. "Borges, Pratt y Corto Maltés: convergencias y malas lecturas". Variaciones Borges. Revista del Centro de Estudios y Documentación Jorge Luis Borges 43 (2017): 159-179. 
Noticia del Blog sobre Stonehenge, sin autor: "Freemasons and Stonehenge. The Masonic Connection", 14 de diciembre de 2016. https://blog.stonehenge-stonecircle.co.uk/2016/12/14/freemasons-and-stonehenge-the-masonic-connection/

Sadoul, Numa. "Una comida con Hugo Pratt". Totem 6 (1978): 87-98.

Serna, Ricardo. "Masones en el Cómic. La Masonería y Corto Maltés". En Estudios Masónicos. Cinco ensayos entorno a la Francmasonería. Santa Cruz de Tenerife: Ediciones Idea, 2008.

Stavish, Mark. Freemasonry: Rituals, Symbols \& History of the Secret Society. Minnesota: Llewellyn Editions, 2007.

Steiner, Marco. "Biografía de Hugo Pratt", Página oficial de Corto Maltés. https://cortomaltese.com/es/hugo-pratt/

Urrero Peña, Guzmán. "América en las historietas de Hugo Pratt". Cuadernos Hispanoamericanos 568 (1997): 19-30.

Viau, Susana. La reina de corazones. No es más que un naipe de la baraja: Las columnas de la periodista que le arruinó los domingos a CFK. Buenos Aires: Penguin Random House Grupo Editorial Argentina, 2013. 


\section{Imágenes}

Fig. 1. Are you freemasonr? (1915). Cartel anunciador de la película homónima.

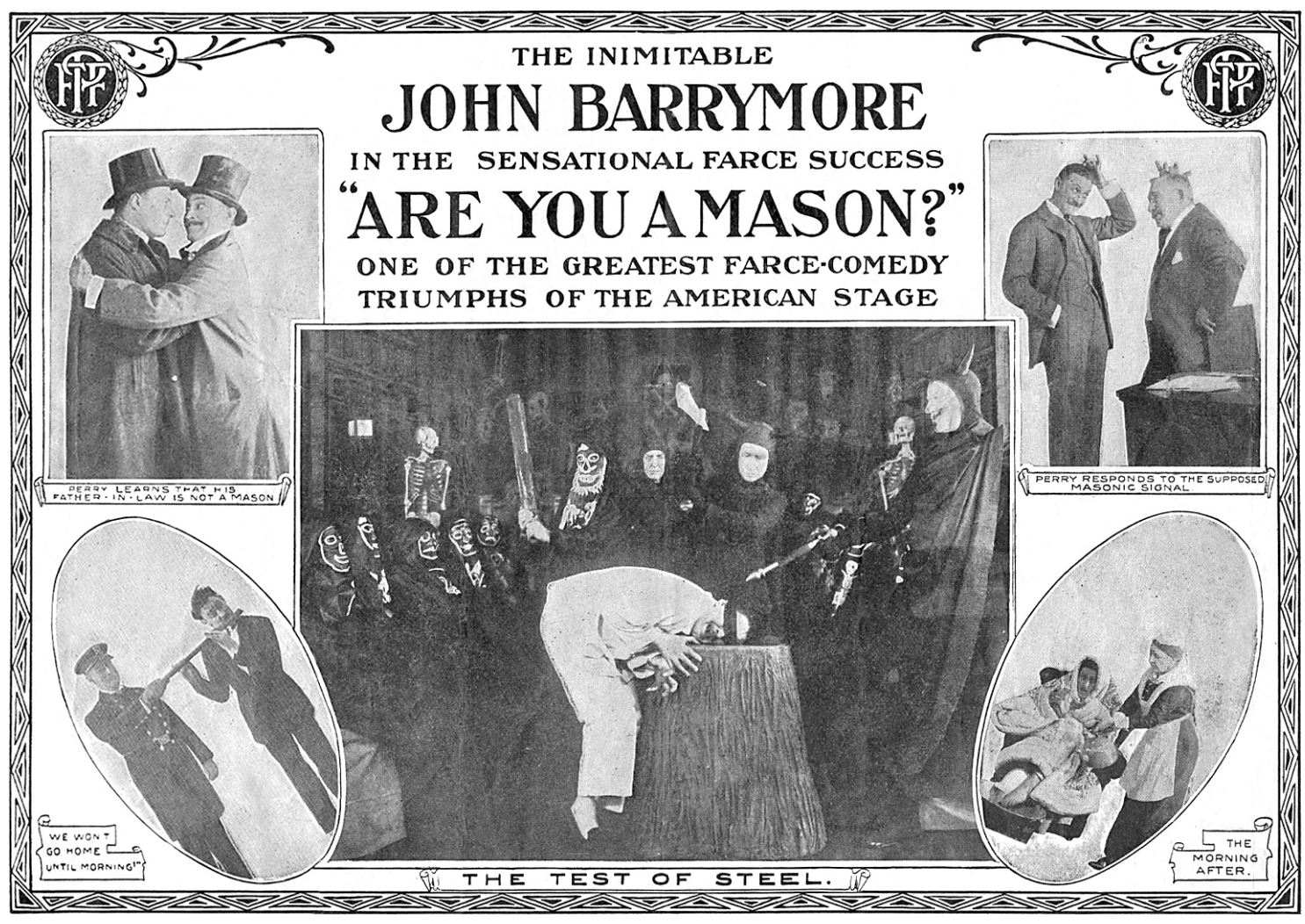


Fig. 2. Viñeta del cómic Fort Wheeling, Hugo Pratt (1992). Iniciación masónica del protagonista Patrick Fitzgerald al grado 4 del REAA, grado ostentado por el propio Pratt. Licencia: Cong. S. A.
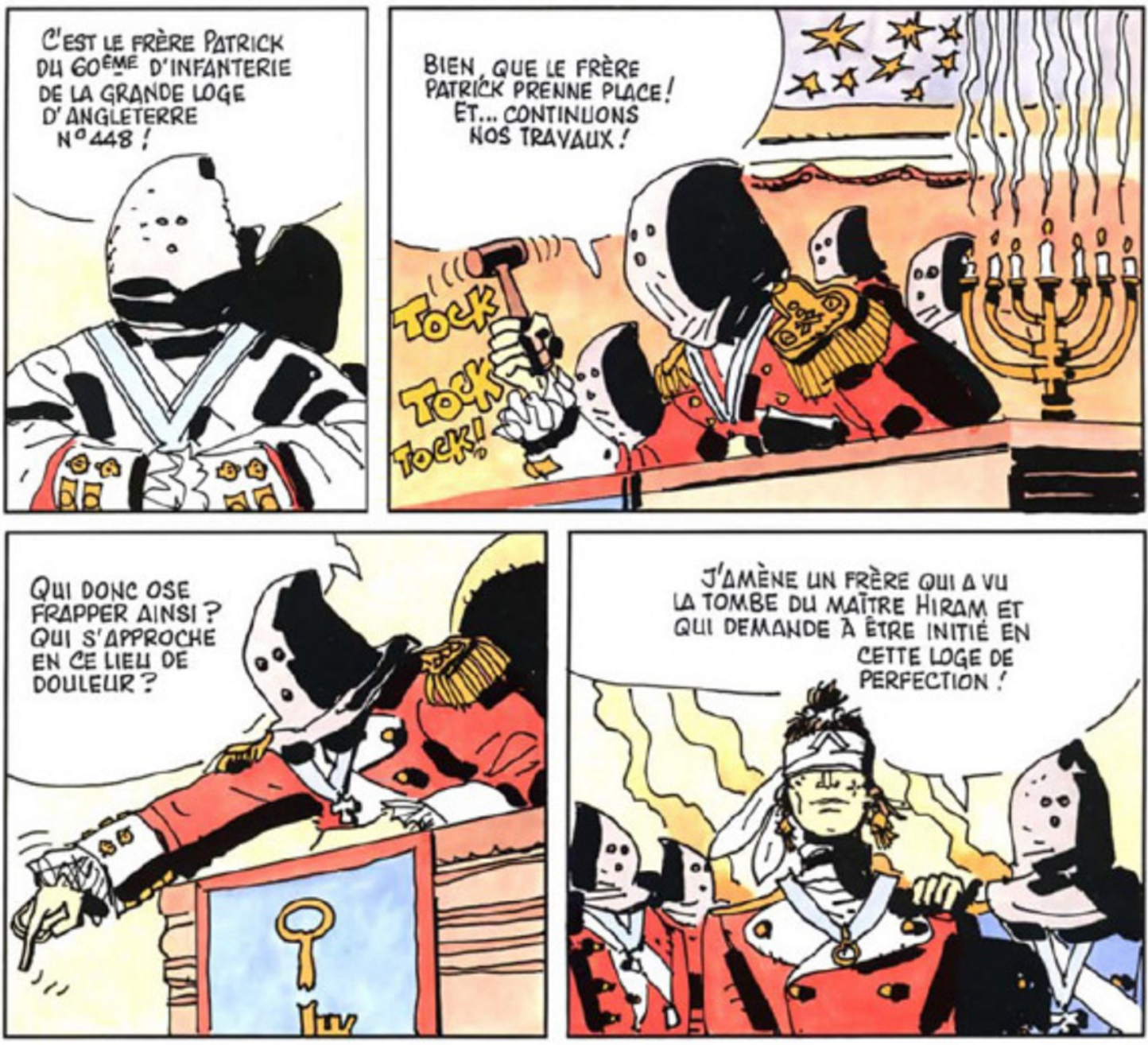
Fig. 3. Viñetas 38-41 del cómic Sueño de una mañana de invierno, Hugo Pratt (c. 1971). Corto queda dormido frente al gran crómlech de Stonehenge y tiene las visiones de la mitología céltica y artúrica. Licencia: Cong. S. A.
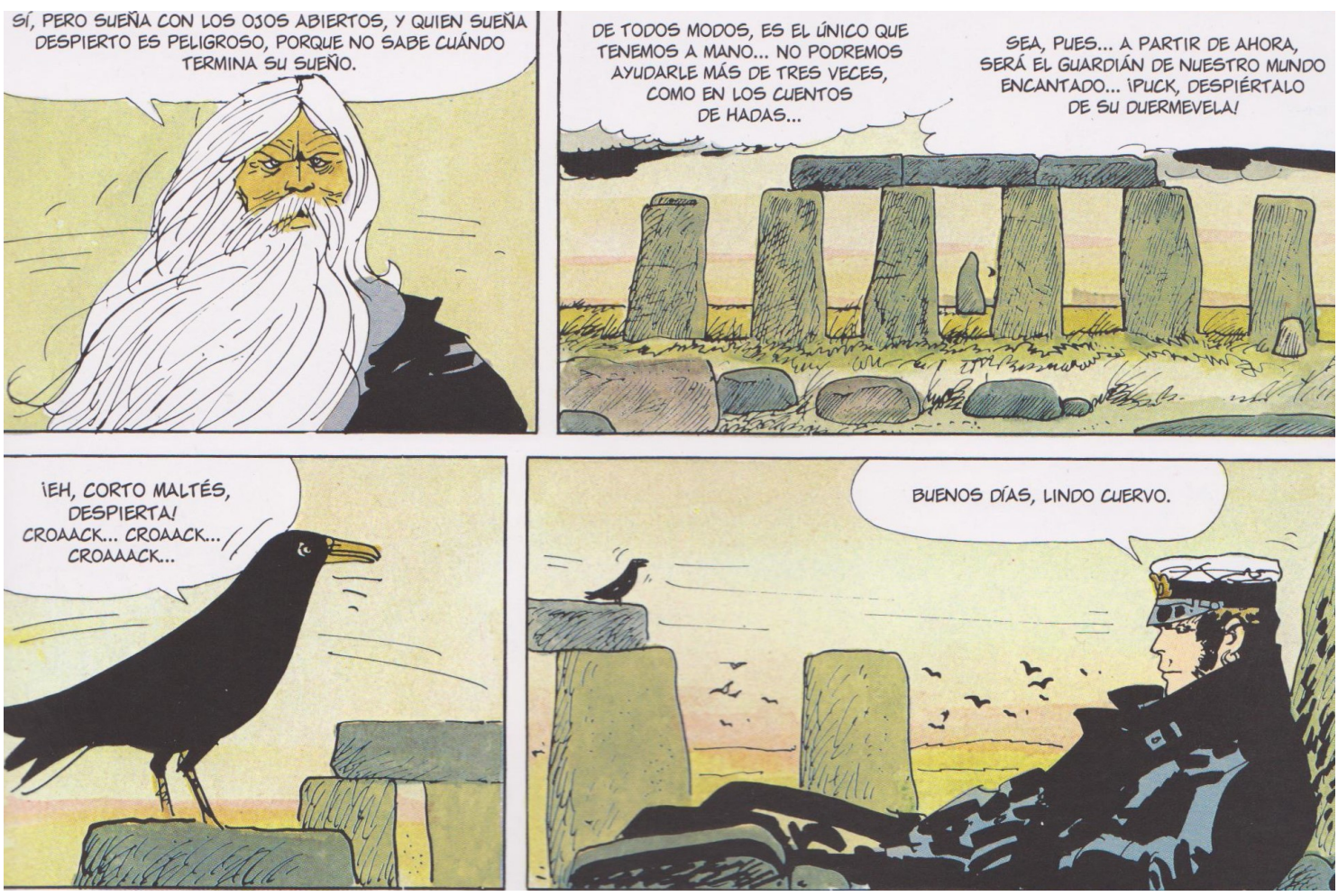

Fig. 4. Viñeta núm. 19 del cómic La Fábula de Venecia, Hugo Pratt (c. 1977). Corto sobre el ajedrezado masónico interrumpe los trabajos de la respetable Logia Hermes. Licencia: Cong. S. A.

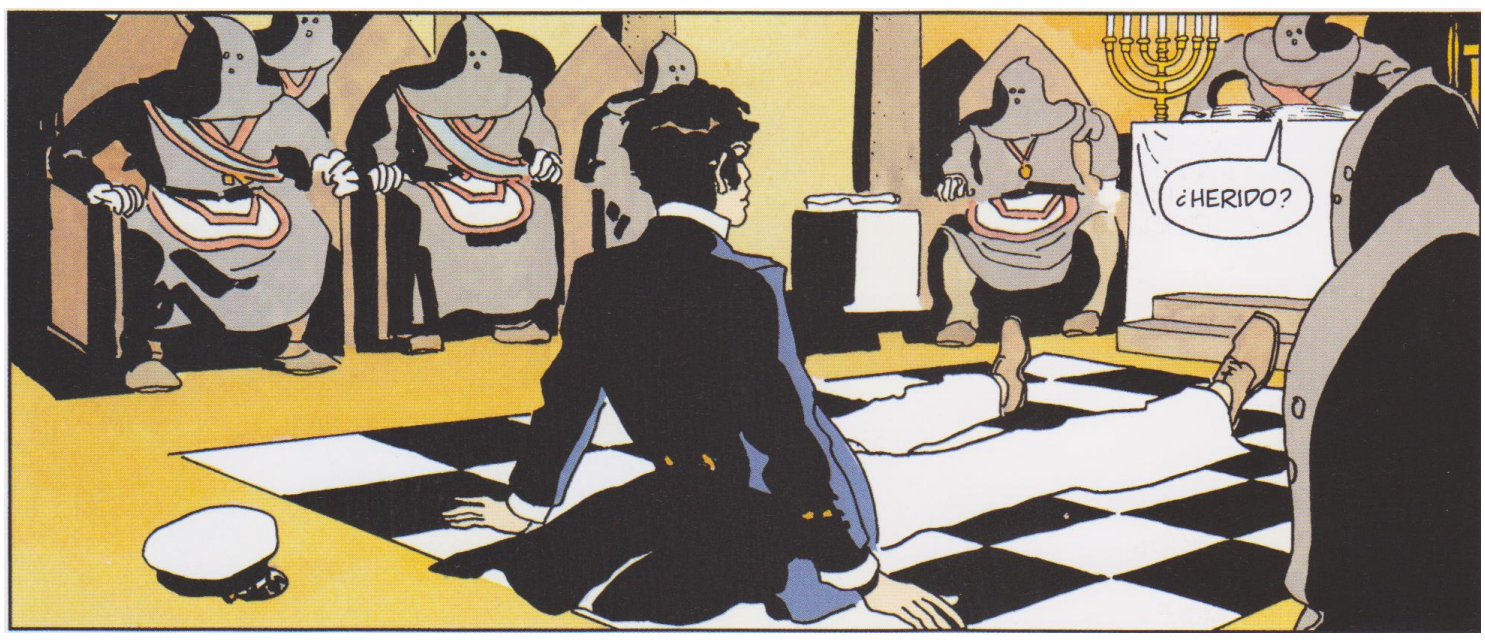


Fig. 5. Viñeta núm. 282 del cómic La Fábula de Venecia, Hugo Pratt (c. 1977). Licencia: Cong. S. A.

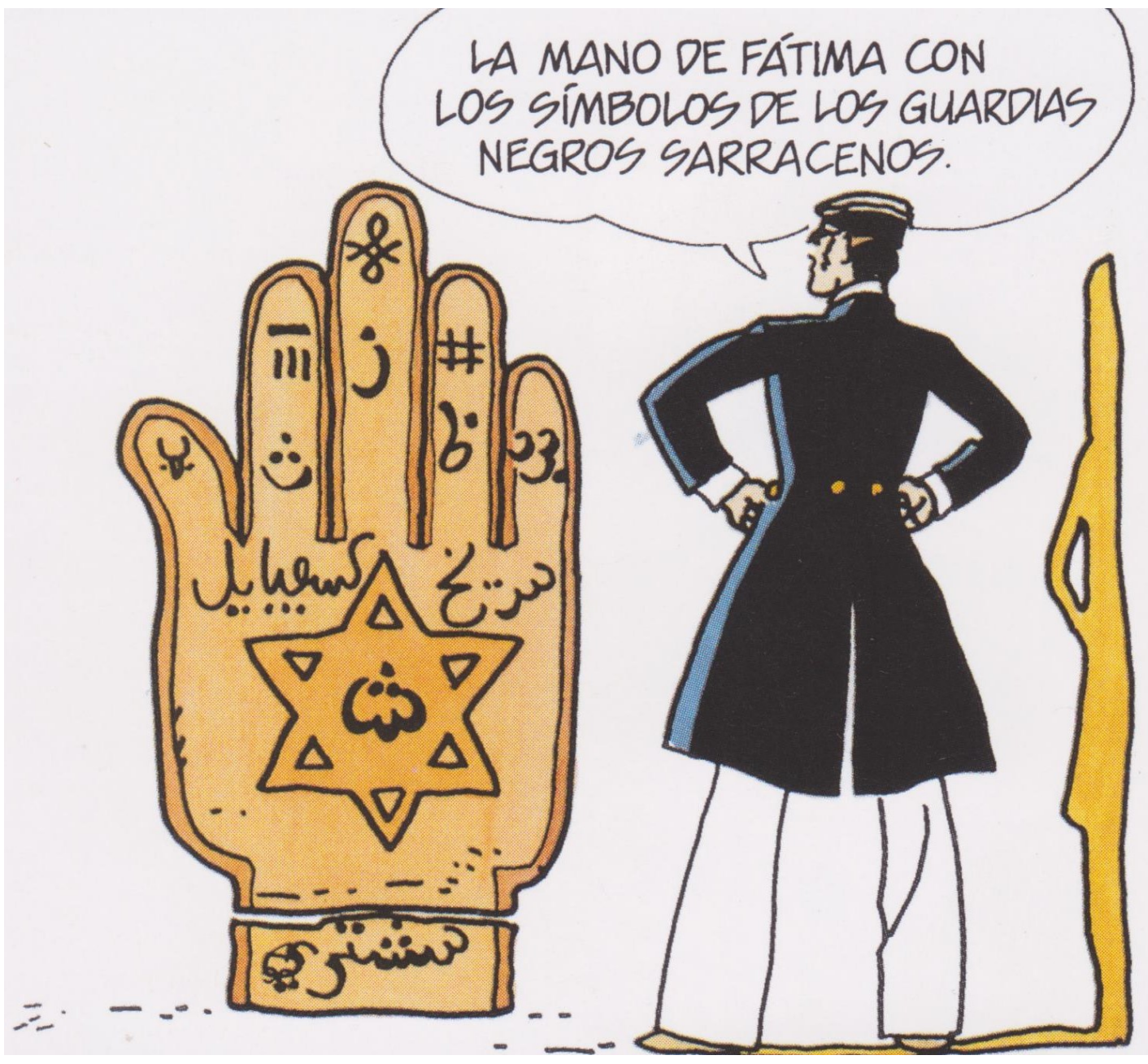


Fig. 6. Viñeta núm. 299 del cómic Las Helvéticas, Hugo Pratt (c. 1987). Licencia: Cong. S. A.

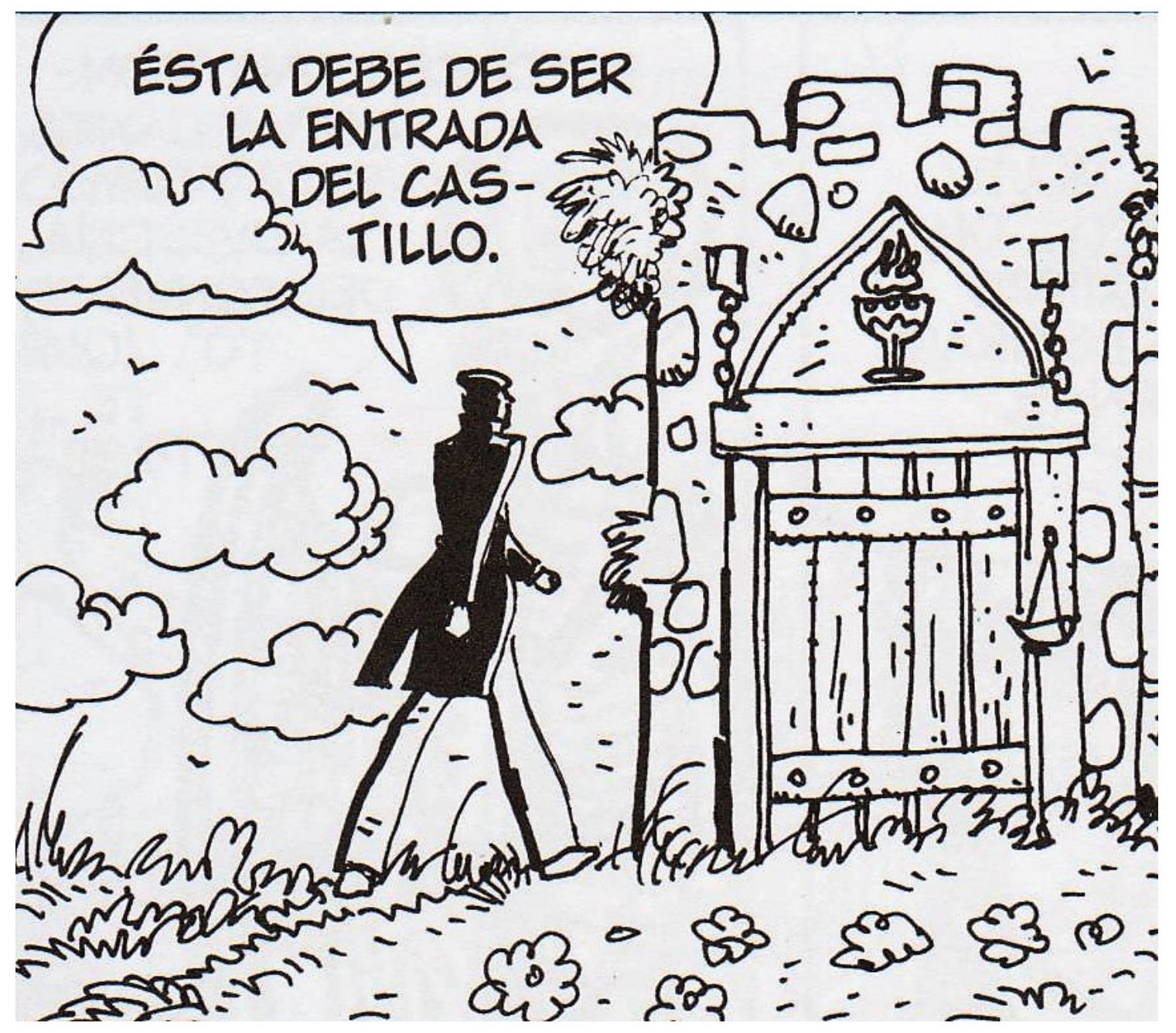

